\title{
Fiscal Rules, Automatic Stabilizers and Discretionary Fiscal Actions: Analyzing an Emerging Economy
}

\author{
Ricardo Ramalhete Moreira \\ Federal University of Espírito Santo (UFES), Brazil \\ Av. Fernando Ferrari, 514, Goiabeiras Vitória - ES - CEP 29075-910, Brazil \\ E-mail: ricardo.moreira@ufes.br
}

Received: Nov. 20, 2015

Accepted: Dec. 11, 2015

Published: Dec. 15, 2015

doi:10.5296/ifb.v2i2.8733

URL: http://dx.doi.org/10.5296/ifb v2i2.8733

\begin{abstract}
This article analyzes the nature of the fiscal rule in Brazil, over the period from January 2005 to July 2012, using a VEC model. The initial findings identify a (weak) fiscal rule, as nominal deficits react counter-cyclically to domestic public debt and inflation changes. However, when we isolate the discretionary component of the fiscal policy its pro-cyclical bias can be highlighted. The estimates contribute to understand the preliminary findings and why such a policy is not enough to impose a sustainable downturn movement on the public debt / GDP ratio in Brazil over the last years.
\end{abstract}

Keywords: public debt, fiscal rule, discretionary component, inflation, Brazil 


\section{Introduction}

Concerns with public debt growth have been an important issue in the theoretical and applied economic literature. Indefinite public debt growth implies social losses such as higher short term interest rates (Sargent \& Wallace, 1981), lower private investments (Blanchard, 2010) and output and inflation changes (Woodford, 2001).

Since 1999, the Brazilian public sector has adopted fiscal targets for its consolidated primary results. Their main goal was to create a nominal result flow consistent with the stability of the net public debt as a proportion of the Gross Domestic Product (GDP). However, the current time series for the Brazilian internal public debt (in relation to GDP) has presented an apparent pattern of increase (Note 1). For instance, the domestic public debt in Brazil was at 42.5\% of the GDP in January 2005, and it increased up to 49.8\% in July 2012 (Graph 1), after fluctuating over time. Indeed, the increase of the Brazilian domestic public debt could be observed since the beginning of the 90's, when it was around 14\% of the GDP (Giambiagi, 2008).

On the other hand, the trend of this series, such as extracted by applying the Hodrick-Prescott (HP) filter, shows a smooth decrease since around August 2008. However, this behavior has to continue for long time if the fiscal authorities' main objective is to obtain a relation equal or below that observed at the beginning of this sample. In this analysis, we are keeping the focus on the sample since January 2005 because it started a period of stability of the inflation target in Brazil, at 4.5\% per year, based on the Broad Consumer Price Index (Note 2).

A ricardian fiscal regime can be defined as one in which the fiscal authority adjusts the policy instrument in order to off-set public debt changes. In other words, in such a regime there exists monetary dominancy, that is, the Central Bank is autonomous in making its monetary policy and not influenced by fiscal requirements. In turn, the autonomy of the Central Bank is a predictable fact under nominal anchors such as the inflation target regime. In a non-Ricardian regime, the Central Bank would not commit itself in the future to cover along with future taxes the new government debt, since some part of the new debt is to be financed through money. In a Ricardian regime, the opposite would be true, with future fiscal revenues being expected to pay for current outstanding government liabilities. In other words, in a Ricardian fiscal regime, primary budget balances are expected to react to government debt, in order to ensure fiscal solvency.

Leeper (1991) defines this kind of coordination as one in which the fiscal policy is passive and the monetary policy is active. And why to off-set public debt growth should be a fiscal and social objective? It is mainly because continuous public debt growth creates a context of volatile and pessimistic expectations regarding the public sector solvency, thereby causing higher short term interest rates; moreover, there exists a literature that regards public debt growth as able to cause real output and inflation effects (Woodford, 2001). Therefore, fiscal authorities are seeking a relevant social goal when they adjust public spending and taxesand then nominal fiscal results - so as to stabilize the public debt. 


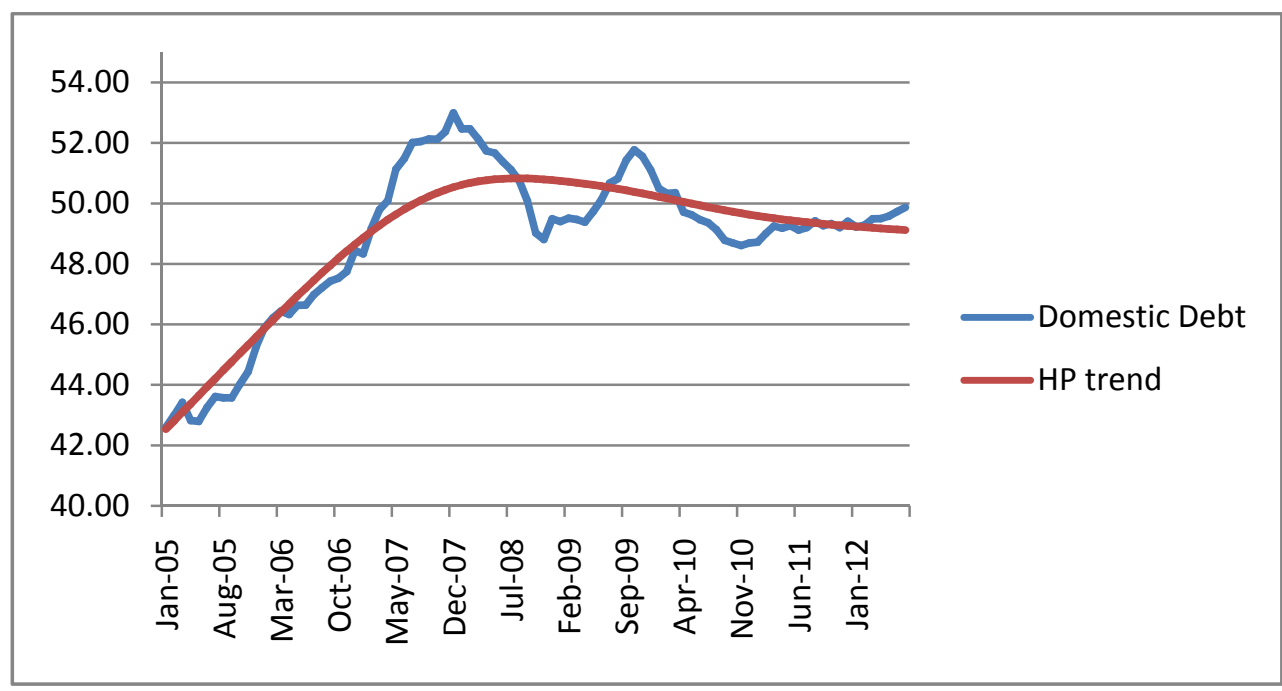

Graph 1. Brazilian internal public debt (\% of GDP) and HP trend: January 2005-July2012

Source: Own elaboration through data from the Brazilian Central Bank.

A fiscal rule, in turn, is nothing more than a way for avoiding persistence of public debt growth, by adjusting primary or nominal results counter-cyclically: the higher (lower) the public debt, the lower (higher) the nominal deficit as a fiscal response, so that the former presents long term stability. Fiscal rules can also be formulated in order to react to real income and/or inflation fluctuations as a mechanism for stabilizing macroeconomic dynamics (Taylor, 2000). Has the Brazilian fiscal authority implemented a fiscal rule as an instrument for stabilizing domestic public debt or another relevant goal, such as the consumer inflation?

Graph 2 shows the behavior of Brazil's broad consumer inflation, its HP trend, inflation targets and nominal fiscal results, from January 2005 to July 2012. These variables were collected from the Brazilian Central Bank's database. At least two relevant things can be noted: on the one hand, in almost all the sample the inflation is higher than its target. On the other hand, the nominal deficit is positive during all the months, denoting a fiscal policy that has impacts on domestic public debt and inflation. It is not for surprise that Graph 1 shows an apparent growth of the domestic public debt since the beginning of this series. Are these remarks a signal of an inexistence of a fiscal rule in Brazil? Or is it a case of weakness of such a rule?

This work aims at testing for the hypothesis of a counter-cyclical fiscal rule in Brazil over the last years. If this hypothesis can be verified then the apparent growth of the domestic public debt should be regarded much more as a transitory than a structural behavior, and probably the reversal of this momentum can be accelerated through improving the (real) parameters of the Brazilian fiscal rule. The empirical strategy is based on the Cointegration and Error Vector Correction approaches (Engle \& Granger, 1987; Johansen \& Juselius, 1990; Johansen, 1991) which aims at verifying long and short term empirical relationships among selected time series. 


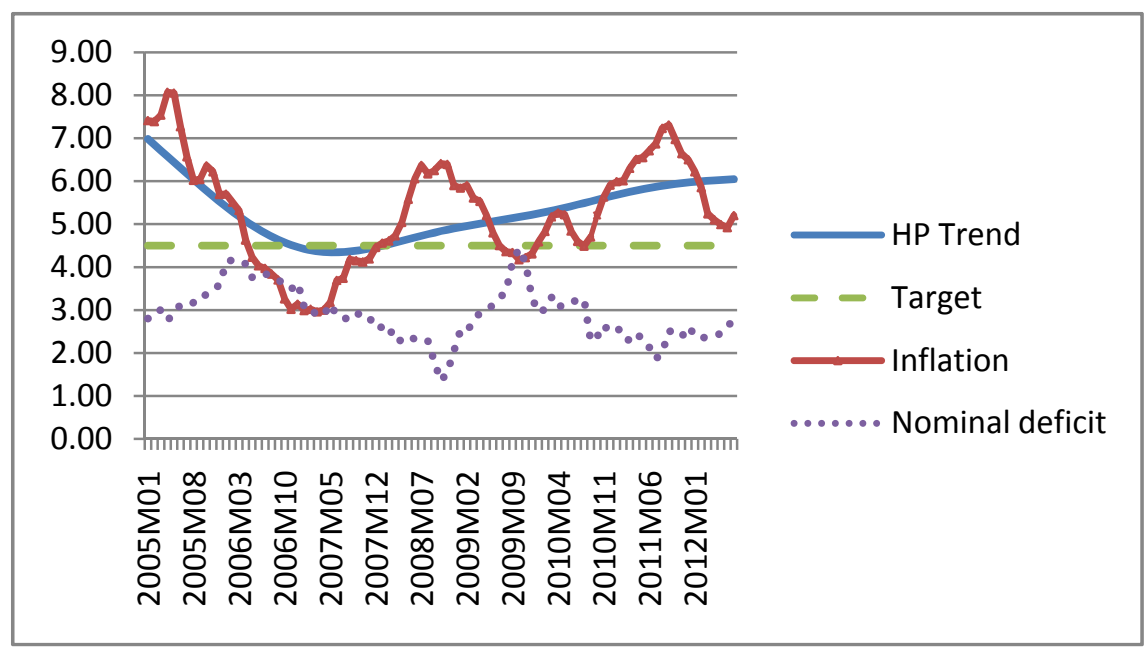

Graph 2. Brazil’s broad consumer inflation (\%), HP trend, inflation target and nominal fiscal deficit (\% GDP): January 2005-July 2012

Source: Own elaboration through data from the Brazilian Central Bank.

Some recent findings can be summarized with respect to fiscal rules. Studying the role of the public debt as a channel for monetary policy in Brazil, Pires \& Andrade (2009) adopted quarterly time series from 1996:1 to 2007:2, and applied Ordinary Least Squares (OLS) and Full Information Maximum Likelihood (FIML) as econometric approaches. They assumed a Brazilian fiscal rule that seeks to react counter-cyclically to output fluctuations: the higher the output gap the lower the fiscal deficit. However, this fiscal rule was not a direct result of their estimations, but, as the authors pointed out, an assumption so as to close the whole model.

Following the research of Garcia \& Rigobon (2004); Lima et al. (2006) and Simonassi (2007); De Mendonça et al. (2009) estimated a fiscal reaction function for Brazil during the period after the Real Plan. They adopted a Markov-Switching approach to deal with the uncertainty regarding possible fiscal regime changes in this sample. They have obtained results showing a fiscal regime break after 2000 in Brazil. From 1994 to 1999, there would be a regime in which the public sector's primary surplus reacted to public net debt changes, while after 2000 there would be another fiscal regime in which the primary surplus did not react to those changes. Moreover, they observed that under both the regimes primary surpluses reacted counter-cyclically to output deviations. However, there were not results demonstrating Brazil's fiscal reactions to inflation changes.

Moreira et al. (2011) tested whether the Brazilian fiscal policy for the period between 1995 to 2008 was active or passive. To analyze fiscal policy transmission mechanisms, they estimated functions by which the public debt/GDP ratio affects investment, primary surplus, output gap and the demand for money. The ratio of public debt to GDP was found to be statistically significant, positively affecting the demand for money and the primary surplus, whereas it was found to negatively affect the level of investment and the output gap. They concluded that the Brazilian regime was non-Ricardian in the context of fiscal dominancy. Regarding 
fiscal rules, the authors found that an increase of $1 \%$ in public debt in relation to GDP was translated into an increase of $0.023 \%$ of primary surpluses as a proportion of GDP; thus, it is possible to say the authors found results demonstrating the existence of a counter-cyclical fiscal rule in Brazil, although they have not investigated the quality of this fiscal rule or its consistency with public debt targets.

In turn, De Mendonça \& Machado (2013) used Brazil's data that comprised the period from December 2003 to July 2011 (92 observations) through OLS and Generalized Method of Moments (GMM) as ways for estimating a model that took into account a fiscal credibility index proposed into the work. They obtained findings demonstrating that the public sector's commitment with public debt management is an important way for building fiscal credibility and that this latter allows a decrease of public bonds indexed to short term interest rates.

Moreover, De Mendonça \& Pinton (2013) studied the Brazilian fiscal policy from 2000 to 2010 by applying OLS and GMM methods and pointed out that there was a change of the fiscal policy conduction after 2007 in Brazil. They have found evidence demonstrating that, from 2000 to 2007, Brazilian fiscal authorities were searching for credibility so that the fiscal policy had been implemented cyclical, while since 2007 the latter has become counter-cyclical in a feasible way, thereby denoting lower fiscal deficits as a response to higher output levels.

The remainder of this article is structured in the following way: section 2 presents the data description and the empirical methodology; section 3, in turn, shows the main results and their analysis. At last, concluding remarks, references and an Appendix are presented in this order.

\section{Data Description and Empirical Strategy}

We adopt the following monthly time series for Brazil from January 2005 to July 2012:

$\mathrm{ND}=$ the public sector's nominal financial requirements or simply the nominal deficit - that includes interest payments - as a proportion of the GDP;

$\mathrm{DEB}=$ the domestic or internal public net debt as a proportion of the GDP;

$\mathrm{P}=$ the consumer inflation measured by the changes of the Broad Consumer Prices Index.

All these time series can be found and collected in the Brazilian Central Bank's database (www.bcb.gov.br). We will analyze the possibility of identifying long and short term relationships through applying cointegration and error correction model, according to Engle \& Granger (1987); Johansen \& Juselius (1990) and Johansen (1991), by trying to verify if there exists at least one cointegration equation among the variables. The detailed process can be defined as:

a) apply a Unit Root test (Augmented Dickey-Fuller test) to identify the integration order of each time series, so that we have conclusions about the viability of using cointegration, given that the latter requires that at least two variables have the same integration order and at the maximum order among the group of variables in the model (Campbell \& Perron, 1991); b) as 
cointegration is a feasible approach, we will test the optimal lag order of the unrestricted Vector Auto-Regressive model that gives an important information to define the lag order of the Vector Error Correction Model; c) identify the optimal specification for the Johansen test; d) identify how many cointegration equations exist in the VEC model through the Trace and Maximum Value statistics; e) analyze long term relationships by the cointegration equation(s) and short term movements by the error correction model; f) try to isolate the discretionary component of the nominal deficit and compare how such a component respond to public debt and consumer inflation in comparison with the nominal deficit as a whole.

\section{Results}

\subsection{Nominal Deficits, Internal Public Net Debt and Inflation}

The three variables of this work are integrated of first order - $\mathrm{I}(1)$ - as the ADF test shows in Table 1. In such a case coitegration and error correction are feasible approaches for testing short and long term relationships among the variables. We adopt 01 lag for the Johansen test because the unrestricted Vector Autoregressive (VAR) model (Table 2) presents 02 lags as an optimal order. As the Vector Error Correction (VEC) model runs with variables in first difference we diminish one lag for balancing the loss of freedom. In turn, Table 3 demonstrates the optimal specification for the Johansen test, that is, one with intercept and without trend in data.

The Trace and Maximum Value statistics have identified only one cointegrating equation for our time series (Table 4). Indeed, the Trace statistics calls for two cointegrating equations, but the Maximum Value calls for only one equation. In such a context, we adopt the more parsimonious specification.

Table 1. Testing the integration order through Augmented Dickey-Fuller approach

\begin{tabular}{|c|c|c|c|c|}
\hline & \multicolumn{2}{|c|}{ Level } & \multicolumn{2}{c|}{ First Difference } \\
\hline Variable & t-Statistic & Prob. ${ }^{*}$ & t-Statistic & Prob. $^{*}$ \\
\hline ND & -2.420877 & 0.1390 & -7.83832 & 0.0000 \\
\hline DEB & -2.133752 & 0.2322 & -4.17177 & 0.0001 \\
\hline P & -2.538575 & 0.1099 & -4.8223 & 0.0000 \\
\hline \multirow{2}{*}{$\begin{array}{c}\text { Critical } \\
\text { Values }\end{array}$} & 1\% level & -3.5056 & $1 \%$ level & -2.5912 \\
\cline { 2 - 5 } & 5\% level & -2.8943 & 5\% level & -1.9445 \\
\hline
\end{tabular}

Source: Own elaboration. 
Table 2. Identification of the optimal lag for the unrestricted VAR

\begin{tabular}{|c|c|c|c|}
\hline Lag & AIC & SC & HQ \\
\hline 0 & 8.760813 & 8.84643 & 8.79527 \\
\hline 1 & 0.44269 & $0.785157^{*}$ & 0.580517 \\
\hline 2 & $0.191614^{*}$ & 0.790931 & $0.432811^{*}$ \\
\hline 3 & 0.243848 & 1.100016 & 0.588416 \\
\hline 4 & 0.357967 & 1.470985 & 0.805905 \\
\hline 5 & 0.476885 & 1.846753 & 1.028193 \\
\hline
\end{tabular}

Note. $(*)$ Indicates the better option.

Source: Own elaboration.

Table 3. Optimal specification of the Johansen cointegration test

\begin{tabular}{|c|c|c|c|c|c|}
\hline Data Trend: & None & None & Linear & Linear & Quadratic \\
\hline Rank or & No Intercept & Intercept & Intercept & Intercept & Intercept \\
\hline No. of CEs & No Trend & No Trend & No Trend & Trend & Trend \\
\hline & \multicolumn{2}{|c|}{ Akaike Information Criteria by Rank (rows) and Model (columns) } \\
\hline 0 & 0.54333 & 0.54333 & 0.58712 & 0.58712 & 0.60507 \\
\hline 1 & 0.50670 & $0.423986^{*}$ & 0.45675 & 0.47359 & 0.48098 \\
\hline 2 & 0.53659 & 0.42653 & 0.44334 & 0.48240 & 0.47698 \\
\hline 3 & 0.66424 & 0.49551 & 0.49551 & 0.55630 & 0.55630 \\
\hline \multicolumn{5}{|c|}{ Schwarz Criteria by Rank (rows) and Model (columns) } \\
\hline 1 & $0.794987 *$ & $0.794987 *$ & 0.92267 & 0.92267 & 1.02450 \\
\hline 2 & 0.926136 & 0.871381 & 0.96007 & 1.00487 & 1.06819 \\
\hline 3 & 1.123798 & 1.069655 & 1.11443 & 1.20942 & 1.23196 \\
\hline
\end{tabular}

Note. (*) Indicates the better option.

Source: Own elaboration.

Table 4. Johansen cointegration test: Trace and Maximum Eigenvalue statistics

\begin{tabular}{|c|c|c|c|c|}
\hline \multicolumn{4}{|c|}{ Unrestricted Cointegration Rank Test (Trace) } & \\
\hline Hypothesized & & Trace & 0.05 & \\
\hline No. of CE(s) & Eigenvalue & Statistic & Critical Value & Prob.** \\
\hline None ${ }^{*}$ & 0.241676 & 46.25551 & 35.19275 & 0.0022 \\
\hline At most $1 *$ & 0.143383 & 21.63417 & 20.26184 & 0.0322 \\
\hline At most 2 & 0.084528 & 7.860104 & 9.164546 & 0.0879 \\
\hline \multicolumn{5}{|c|}{ Unrestricted Cointegration Rank Test (Maximum Eigenvalue) } \\
\hline Hypothesized & & Max-Eigen & 0.05 & \\
\hline No. of CE(s) & Eigenvalue & Statistic & Critical Value & Prob.** \\
\hline None * & 0.241676 & 24.62134 & 22.29962 & 0.0233 \\
\hline At most 1 & 0.143383 & 13.77406 & 15.8921 & 0.1045 \\
\hline At most 2 & 0.084528 & 7.860104 & 9.164546 & 0.0879 \\
\hline
\end{tabular}

Source: Own elaboration. 


\section{I Macrothink}

In sequence, we estimate the VEC model with 01 lag and with intercept and no trend in data. Thus, Table 5 presents the estimation for the cointegrating equation, which can be useful in showing long term relationships for our model. We have applied all the time series in $\log$ form so that an elasticity meaning can be extracted.

Thus, when the Brazilian domestic public debt increases 1\%, the nominal deficit decreases 9.5\% under the studied sample. This kind of reaction expresses a counter-cyclical behavior of fiscal flow in Brazil with regard to the public sector's domestic debt. The results also show a counter-cyclical nominal deficit regarding inflation. An increase of $1 \%$ in the latter comes jointly with a decrease of $2.5 \%$ in the former. These two long term counter-cyclical reactions have statistical significance at $1 \%$ of confidence.

Table 5. Estimation for the cointegrating equation

\begin{tabular}{|c|c|}
\hline \multicolumn{2}{|c|}{ Cointegrating Equation: } \\
\hline LOG(ND) & 1.000 \\
\hline \multirow{3}{*}{ LOG(DEB) } & -9.577 \\
\cline { 2 - 2 } & $(2.157)$ \\
\cline { 2 - 2 } & {$[-4.439]^{*}$} \\
\hline \multirow{3}{*}{ LOG(P) } & -2.561 \\
\cline { 2 - 2 } & $(0.471)$ \\
\cline { 2 - 2 } & {$[-5.435]^{*}$} \\
\hline \multirow{3}{*}{ Intercept } & 42.670 \\
\cline { 2 - 2 } & $(8.829)$ \\
\cline { 2 - 2 } & {$[4.832]^{*}$} \\
\hline
\end{tabular}

Note. ( ) to standard error, [ ] to t-statistics and * to statistical significance at $1 \%$.

Source: Own elaboration.

We can also observe short term corrections by means of reactions of the times series' first difference relating long term disequilibria. These corrections are estimated by the Error Correction model (Table 6). The domestic public debt is the only variable that adjusts for long term disequilibria (at 1\% of confidence). It means that when the nominal deficit is higher than its long term equilibrium value, the domestic public debt decreases so as to correct the cointegrating relationship. However, the velocity of this correction is very low, given that the debt/GDP ratio decreases only $0.006 \%$ per month facing $1 \%$ of disequilibrium in the cointegrating equation. In other words, the full correction requires around 166 months (or about 13 years) to occur, which is a term without economic meaning for fiscal adjustments. 
Table 6. Error correction model

\begin{tabular}{|c|c|c|c|}
\hline Error Correction: & $\mathbf{D}(\mathbf{L O G}(\mathbf{N F S P}))$ & $\mathbf{D}(\mathbf{L O G}(\mathbf{D E B}))$ & $\mathbf{D}(\mathbf{L O G}(\mathbf{P}))$ \\
\hline $\mathbf{u}_{\mathbf{t}-\mathbf{1}}$ & -0.012702 & -0.00648 & -0.004612 \\
\hline & $(0.02271)$ & $(0.00144)$ & $(0.01084)$ \\
\hline & {$[-0.55921]$} & {$[-4.50667]^{*}$} & {$[-0.42558]$} \\
\hline
\end{tabular}

Note. "u" to cointegration equation's residuals; ( ) to standard error, [ ] to t-statistics, D to first difference and * to statistical significance at $1 \%$.

Source: Own elaboration.

\subsection{Considering the Discretionary Component versus Automatic Stabilizers into the Nominal} Deficit

When the nominal deficit reacts to inflation and public debt changes, such a reaction can occur in part due to the role of the automatic stabilizers, which naturally respond counter-cyclically to the output dynamics. However, the discretionary or exogenous component of the nominal deficit is fundamental to evaluate the quality of the fiscal rule (Taylor, 2000; 2009), because through the behavior of that component we can precisely identify if the fiscal authorities are really committed for stabilizing public debt or inflation rates.

The first step to evaluate the behavior of the nominal deficit's discretionary component is to measure it. A possible way of measuring such component is by means of a simple regression that explains the nominal deficits from output changes. In this case, the residuals of this regression can be regarded as the exogenous or discretionary part of the nominal deficit, that is, the quantum that is not correlated with output changes over time. Let Y be Brazil's output over the studied sample, such that:

$$
N D_{t}=C+\phi Y_{t}+v_{t}
$$

Given that $\phi<0$ accounting for automatic stabilizers and C is a constant, the regression's disturbances are expressed by $v$, which is our measure of the discretionary component. This simple regression can be estimated by OLS and its main statistics are reported on Table 7, using the Brazilian Central Bank's activity index (Source: Brazilian Central Bank) as a proxy for output $(\mathrm{Y})$ in monthly basis. The adjusted $\mathrm{R}^{2}$ is 0.248 , meaning that around $75 \%$ of the nominal deficits in Brazil have occurred by the fiscal authorities' discretionary actions or by exogenous shocks. As $\mathrm{Y}$ has unit root in level based on the ADF test, we regress both the variables (ND \& Y) in log-level values and test for cointegration through the Engle \& Granger (1987) approach, i.e. testing for unit root in the residual series. Such test has rejected this null hypothesis, thereby validating the regression of the Table 7 in log-level values. Hence, in the presence of an increase of $1 \%$ in Brazil's output there is a reduction of $1.3 \%$ in the nominal deficit, due to the role of the automatic stabilizers. 
Table 7. The role of automatic stabilizers for nominal deficits in Brazil

\begin{tabular}{|c|c|c|c|c|}
\hline Variable & Coefficient & Std. Error & t-Statistic & Prob. \\
\hline C & 7.401 & 1.147 & 6.451 & 0.0000 \\
\hline LOG(Y(-1)) & -1.313 & 0.237 & -5.544 & 0.0000 \\
\hline
\end{tabular}

Source: Own elaboration.

\subsection{Testing for Different Responses of $v$ and ND}

In sequence, as a mean for comparison between the responses of ND and $v$ facing DEB and P changes we can specify two unrestricted (short-term) Vector Autoregressive models: the first one (VAR1), containing ND, DEB and P; and the second one (VAR2), with v, DEB and P. As we will perform short-term relationships all the I (1) variables should be used in their first difference form. With such a method, it will be possible to assess how $v$ and D (ND) comparatively reacts to $\mathrm{D}(\mathrm{DEB})$ and $\mathrm{D}(\mathrm{P})$ shocks over time.

Both VAR1 and VAR2 have an optimal 01 lag and they do not present residual correlation based on LM tests (02 and 04 lags). Besides they have parameter stability as shown by the inverse roots test. To analyze the dynamic relationships among the selected series, we adopted generalized impulse-response functions (Note 3).

As we can view (Figure 1), D (DEB) positive shocks generate more persistent responses of the discretionary nominal deficit $(\mathrm{v})$ in comparison with the nominal deficit as a whole (ND, which also includes the automatic stabilizer component). While the former presents a positive response with statistical significance until about the $8^{\text {th }}$ month after the D (DEB) shock, the latter presents it over less than two months after such a shock.

However, an increase of the nominal deficit as a response to D (DEB) positive shocks means that fiscal authorities are acting in a pro-cyclical manner, thus making the stabilization of the internal public debt more difficult to occur.

Hence, when we isolate the role of automatic stabilizers, thereby isolating the discretionary component, we can note that Brazilian fiscal authorities are more pro-cyclical than the gross data suggest. That is, the automatic stabilizers contribute to hide some part of the pro-cyclical discretionary element. In turn, D (P) positive shocks do not impact nominal deficits and $v$ with statistical significance. 

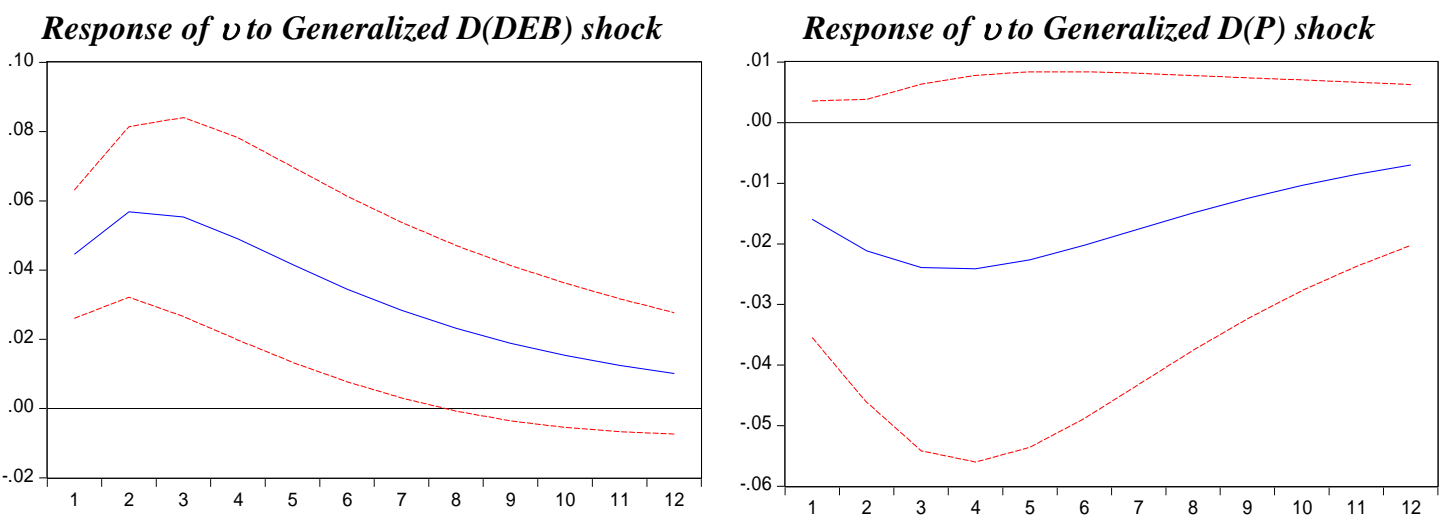

Response of $D(N D)$ to Generalized $D(D E B)$ shock
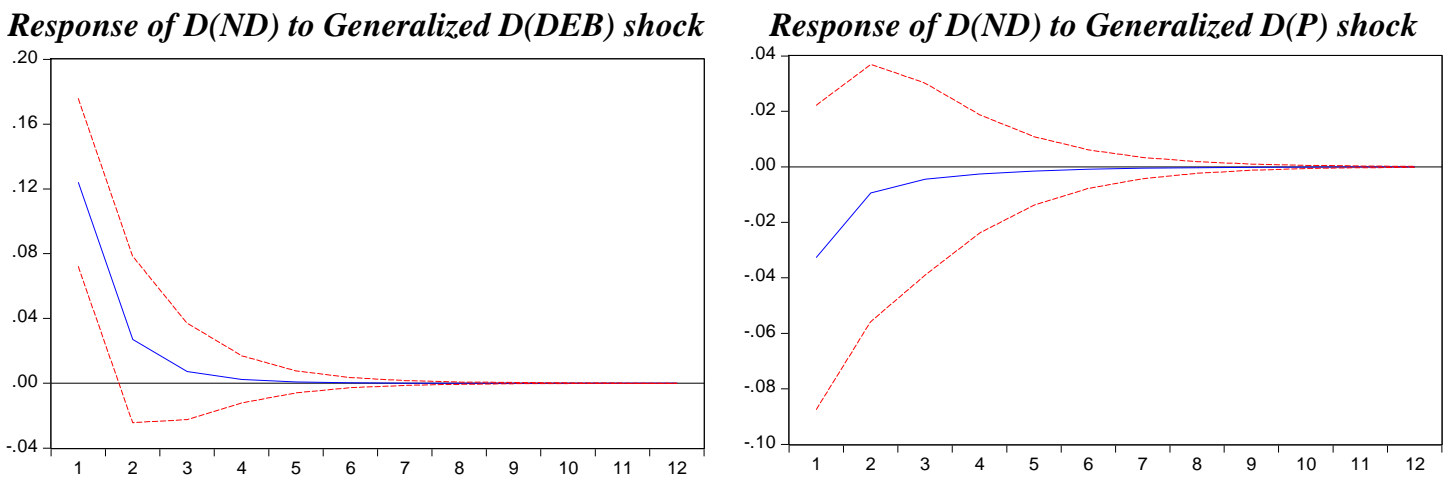

Figure 1. Responses of and ND to Generalized D (DEB) and D (P) shocks

Source: Own elaboration.

\section{Concluding Remarks}

The Brazilian public sector has a fiscal rule as the cointegrating equation has presented values that demonstrate counter-cyclical reactions of the nominal deficit to both public debt and consumer inflation, but such a fiscal rule seems not to be appropriate to stabilize the domestic public debt in relation to GDP.

Therefore, the trajectory of an increasing domestic public debt in Brazil, from 2005 to 2012, is based on a weak fiscal rule. The reaction of nominal deficits to debt and inflation changes is possibly lower than the necessary magnitude to impose a downturn movement on the domestic public debt. However, the counter-cyclical movements of nominal deficits estimated in our econometric analysis could be the consequence of fiscal automatic stabilizers and not of discretionary changes or fiscal impulses. Hence, we aimed at isolating the discretionary component of nominal deficits and such a component made clear the pro-cyclical spirit of the Brazilian fiscal policy. As an increase of public debt and inflation has a counterpart in income expansion, at least in short term, the reduction of nominal deficits into the cointegrating analysis probably would be due to higher tax revenue, and not to discretionary spending or budget adjustments.

As we just show above, the Brazilian internal public debt is very rigid in the face of long term disruptions, given that its short term reaction takes too long time to occur entirely. Moreover, 
the evidence of no short term reaction of nominal deficits to long term disequilibria also suggests a low flexibility of fiscal conditions in Brazil. It is not for surprise the fact of a continuous nominal deficit during the studied years. A more flexible fiscal regime would create nominal surpluses in periods of high GDP growth. The fiscal inertia and the pro-clyclical discretionary component estimated in this work make more difficult to impose a sustained downturn trajectory of the domestic public debt.

Possible ways for enhancing the flexibility of fiscal conditions in short term are: i) signaling targets for primary surpluses or implementing transparent and adjustable targets for nominal deficits facing debt and inflation changes; ii) systematically announcing targets and projections for domestic public debt as a proportion of the GDP, thereby contributing with the public's expectations regarding fiscal requirements; iii) reducing the amount of public spending linked by law to specific areas or percentages, that is, increasing the amount of public spending that federal and local governments can reallocate in Brazil facing social and economic changes; iv) developing public management strategies that aim at improving spending efficiency and budget flexibility, thereby allowing nominal result reactions in association with public debt targets in long term.

\section{References}

Blanchard, O. (2010). Ten commandments for fiscal adjustment in advanced economies. The International Monetary Fund's Global Economy Forum, June 24.

Campbell, J. Y., \& Perron, P. (1991). Pitfalls and opportunities: what macroeconomists should know about unit roots. In B. O. Jean \& F. Stanley (Eds.), NBER Macroeconomics (vol. 6). MIT Press. http://dx.doi.org/10.2307/3585053

De Mendonça, M. J. C., \& Santos, C. H. M. (2009). dos; Sachsida, A. Revisitando a função de reação fiscal no Brasil pós-Real: uma abordagem de mudanças de regime. Estudos Econômicos, 39(4). http://dx.doi.org/10.1590/S0101-41612009000400007

De. Mendonça, H. F., \& Machado, M. R. (2013). Public debt management and credibility: Evidence from an emerging economy. Economic Modelling, 30, 10-21. http://dx.doi.org/10.1016/j.econmod.2012.09.009

De.Mendonça, H. F., \& Pinton, O. V. F. (2013). Fiscal Cyclicality in the Brazilian Economy: Something Is Changing. Latin American Business Review (Binghamton, N.Y.), 14, 163-174. http://dx.doi.org/10.1080/10978526.2013.808951

Engle, R. F., \& Granger, C. W. J. (1987). Co-integration and error correction: representation, estimation and testing. Econometrica, 55(2), 251-276. http://dx.doi.org/10.2307/1913236

Garcia, M., \& Rigobon, R. (2004). A risk management approach to emerging market's sovereign debt sustainability with an application to Brazilian data. NBER Working Paper, $\mathrm{n}$. 10336.

Giambiagi, F. (2008). 18 anos de política fiscal no Brasil: 1991/2008. Economia Aplicada, Dec 2008, 12(4), 535-580. http://dx.doi.org/10.1590/S1413-80502008000400002 
Johansen, S. (1991). Estimation and hypothesis testing of cointegration vectors in Gaussian vector autoregressive models. Econometrica, 59(6), 1551-1580. http://dx.doi.org/10.2307/2938278

Johansen, S., \& Juselius, K. (1990). Maximum likelihood estimation and inference on cointegration: with applications to the demand for money. Oxford Bulletin of Economics and Statistics, 52, 169-210. http://dx.doi.org/10.1111/j.1468-0084.1990.mp52002003.x

Koop, G., Pesaran, M. H., \& Potter, S. M. (1996). Impulse response analysis in nonlinear multivariate models. Journal of Econometrics, 74, 119-147. http://dx.doi.org/10.1016/0304-4076(95)01753-4

Leeper, E. M. (1991). Equilibria Under 'Active' and 'Passive’ Monetary and Fiscal Policies. Journal of Monetary Economics, $\quad 27(1), \quad$ 129-147. http://dx.doi.org/10.1016/0304-3932(91)90007-B

Lima, L. R., Sampaio, R., \& Gaglianone, W. (2006). Debt ceiling and fiscal sustainability in Brazil: a quantile autoregression approach. Mimeo. Rio de Janeiro: EPGE/FGV.

Lutkenpohl, H. (1991). Introduction to Multiple Time Series Analysis. Berlin: Springer. http://dx.doi.org/10.1007/978-3-662-02691-5

Moreira, T. B. S., Soares, F. A., Sachsida, A., \& Loureiro, P. A. (2011). The Interaction of Monetary and Fiscal Policy: The Brazilian Case. Modern Economy, 2, 114-123. http://dx.doi.org/10.4236/me.2011.22016

Pesaran, M. H., \& Shin, Y. (1998). Generalized Impulse Response Analysis in Linear Multivariate Models. Economics Letters, 17-29. http://dx.doi.org/10.1016/S0165-1765(97)00214-0

Pires, M. C., \& Andrade, J. P. (2009). Uma análise da transmissão da política monetária e o canal da dívida pública com aplicação aos dados brasileiros. Economia Aplicada, 13(4), 439-462. http://dx.doi.org/10.1590/S1413-80502009000400005

Sargent, T., \& Wallace, N. (1981). Some unpleasant monetarist arithmetic. Quarterly Review Federal Reserve Bank of Minneapolis, 5(3), 1-17.

Simonassi, A. (2007). Função de resposta fiscal, múltiplas quebras estruturais e a sustentabilidade da dívida pública no Brasil. XXXV ENCONTRO DA ANPEC, Recife-PE.

Taylor, J. B. (2000). Reassessing Discretionary Fiscal Policy. Journal of Economic Perspectives, 14(3), 21-36. http://dx.doi.org/10.1257/jep.14.3.21

Woodford, M. (2001). Fiscal Requirements for Price Stability. Journal of Money, Credit and Banking, 33, 669-728. http://dx.doi.org/10.2307/2673890

\section{Notes}

Note 1 . In the current discussion we have considered the internal public net debt and not the 
total public net debt. It is because Brazil's total public net debt has decreased in the studied period mainly as consequence of the Central Bank's foreign currency reserve growth. However, the public debt dominated in domestic currency e.g. the internal public debt has increased in the same period. Many Brazilian authorities and analysts have inappropriately regarded the reduction of the total public net debt as signal of fiscal responsibility in Brazil, but this assumption does not remain if we look at the debt created in domestic currency. This latter and not that former is the correct way for analyzing Brazil’s underlying fiscal quality.

Note 2. Hence, this sample avoids problems of changing the inflation target, thereby making easier to discuss issues of coordination between monetary and fiscal policies.

Note 3. Unlike the conventional method that assumes the Cholesky ordering and it is sensible to re-ordering of the series (Lutkenpohl, 1991), the generalized impulse-response functions do not have such sensibility into the VAR (Koop et al., 1996; Pesaran \& Shin, 1998) and thus avoid tests for defining the ordering process of the series

\section{Copyright Disclaimer}

Copyright for this article is retained by the author(s), with first publication rights granted to the journal.

This is an open-access article distributed under the terms and conditions of the Creative Commons Attribution license (http://creativecommons.org/licenses/by/3.0/). 